\title{
PENGARUH PRESTASI KERJA DAN SENIORITAS TERHADAP PROMOSI JABATAN PADA PT. BANK BENGKULU CABANG UTAMA
}

\author{
${ }^{1}$ Meilaty Finthariasari, ${ }^{2}$ Desi Purnama Sari \\ 1,2Prodi Manajemen, Fakultas Ekonomi, Universitas Muhammadiyah Bengkulu \\ E-mail : ${ }^{1}$ mheyfinta@umb.ac.id, ${ }^{2}$ desipurnama97@gmail.com
}

\begin{abstract}
ABSTRACK
This study studies any factors that can improve the low performance of employees either partially or simultaneously. There are several factors that will be discussed in this study, discussed work Performance $\left(X_{1}\right)$, and seniority $\left(X_{2}\right)$. The object of this research is the company employees of PT Bank Bengkulu Cabang Utama, which gathered 60 people. The sampling method in this study is total sampling by taking an object or participating to take a sample. In this research the authors use the method of data collection by observation and questionnaires. There are several data analysis techniques used in this study, including using the instrument test, classic assumption test, respondent response analysis, multiple linear regression analysis, determinant coefficient, and also hypothesis testing. From the results of tests that have been carried out it can be concluded that the work performance reward and seniority variables have a partial or simultaneous effect on employee performance at PT Bank Bengkulu Cabang Utama.
\end{abstract}

Keywords : Work Performance, Seniority, Promotion of Position

\begin{abstract}
ABSTRAK
Penelitian ini bertujuan untuk mengetahui faktor apa saja yang dapat mempengaruhi rendahnya Promosi jabatan baik secara parsial maupun simultan. Ada beberapa faktor yang akan dibahas dalam penelitian ini, diantaranya Prestasi kerja $\left(\mathrm{X}_{1}\right)$ dan Senioritas $\left(\mathrm{X}_{2}\right)$. Obyek dalam penelitian ini adalah seluruh karyawan pada PT Bank Bengkulu Cabang Utama yang berjumlah 60 orang. Metode pengambilan sampel dalam penelitian ini adalah total sampling yaitu dengan mengambil seluruh obyek atau populasi untuk dijadikan sampel. Dalam penenlitian ini penulis menggunakan metode pengumpulan data dengan cara observasi, dan kuisioner. Ada beberapa teknik analisis data yang digunakan dalam penelitian ini, diantaranya dengan menggunakan uji instrument, uji asumsi klasik, analisis tanggapan responden, analisis regresi linier berganda, koefisien determinan, dan juga uji hipotesis. Dari hasil pengujian yang telah dilakukan dapat disimpulkan bahwa variabel Prestasi kerja dan Senioritas berpengaruh secara parsial maupun simultan terhadap Promosi jabatan pada PT. Bank Bengkulu Cabang Utama.
\end{abstract}

Kata kunci : Prestasi kerja, Senioritas, Promosi Jabatan 


\section{PENDAHULUAN}

Pada PT. Bank Bengkulu Cabang utama berusaha memberikan yang terbaik bagi karyawan agar kinerja para karyawan efektif sehingga berdampak positif bagi perusahaan. Permasalahan dalam mempromosikan karyawan berdasarkan dari hasil observasi di PT. Bank Bengkulu Cabang Utama menyatakan bahwa dalam membuat keputusan promosi dibutuhkan berbagai pertimbangan, apabila terdapat keputusan yang salah dalam melaksanakan promosi jabatan, maka akan menimbulkan efek samping yang tidak baik bagi pegawai dan perusahaan, yang semuanya akan mengakibatkan Prestasi kerja yang menurun sehingga harapan perusahaan untuk meningkatkan produktivitas tidak akan tercapai.

Faktor yang perlu diperhatikan terkait apakah karyawan sebuah perusahaan layak untuk mendapatkan promosi jabatan atau tidak adalah dengan melihat prestasi dari karyawan tersebut. Menurut Finthariasari (2020) promosi jabatan karyawan terjadi juga dilihat dari komitmen kerja karyawan yang tentunya akan mendorong kinerja karyawan. Proses yang dilakukan perusahaan dalam mengevaluasi kinerja para karyawan sering disebut dengan penilaian prestasi kerja (Mangkuprawira,2004:42). karyawan yang memiliki prestasi kerja yang baik dapat diketahui setelah ia melaksanakan tugastugas yang dibebankan kepadanya sesuai dengan standar yang ditetapkan,sehingga perusahaan dapat memberikan imbalan yang sepantasnya atas prestasi kerja tersebut.

Faktor lain yang mempengaruhi promosi jabatan pada karyawan adalah Prestasi kerja dan senioritas. PT. Bank Bengkulu Cabang Utama dalam hal ini melaksanakan upaya pengembangan SDM dengan promosi jabatan. Upaya ini diharapkan dapat menjaga kinerja memperbaiki, mendorong semangat kerja karyawan dalam meningkatkan kinerjanya agar lebih baik. Pengalaman kerja dibutuhkan para pegawai yang berpengalaman, karena banyaknya pengalaman dapat memberikan dapat yang positif seperti kemampuan dan ide-ide yang lebih baik, sebagai pengambilan keputusan dalam promosi jabatan.

Berdasarkan observasi dengan 8 karyawan keadaannya kurang optimal dalam mempromosikan karyawan tetap, dimana ada karyawan yang mendapat promosi jabatan bukan merupakan orang yang sesuai dengan ahlinya sehingga dapat berpengaruh pada visi dan misi perusahaan. Berdasarkan hasil observasi dari executive secretary menyatakan bahwa ada dua jalur untuk dapat dipromosikan yaitu jalur seleksi dan jalur pemberkasan yang dilihat dari prestasi kerja dan pengalaman kerja sebagai dasar untuk karyawan agar dapat dipromosikan Permasalahan promosi jabatan pada PT. Bank Bengkulu Cabang Utama adalah persaingan dengan karyawan lain yang juga ingin dipromosikan dengan mengikuti tahapan/seleksi penilaian yang diselenggarakan oleh bagian SDM, selain itu target-target pekerjaan yang diisyaratkan sudah mampu dicapai tapi belum dipromosikan.

Tabel 1

Hasil Survei Awal

Karyawan

\begin{tabular}{|c|l|c|c|}
\hline No & \multicolumn{1}{|c|}{ Variabel } & $\begin{array}{l}\text { Jumlah } \\
\text { Pelanggan }\end{array}$ & $\begin{array}{c}\text { Presentasi } \\
(\%)\end{array}$ \\
\hline 1 & Prestasi Kerja & 5 Orang & 60 \\
\hline 2 & Senioritas & 3 Orang & 40 \\
\hline \multicolumn{2}{|c|}{ Total Karyawan } & 8 Orang & 100 \\
\hline
\end{tabular}

Sumber : survei awal, 2019.

Hasil wawancara awal yang peneliti lakukan tersebut, diperoleh bahwa menurut responden, mereka menyatakan bahwa tiga factor yang dapat mempengaruhi promosi jabatan adalah prestasi kerja, senioritas, dan prestasi kerja mempengaruhi promosi jabatan. Dalam penelitian saat ini, peneliti 
akan mencoba melakukan penelitian terkait dengan isu promosi jabatan yang terjadi di lingkungan kantor PT. Bank Bengkulu Cabang Utama. adalah:

Adapun tujuan penelitian saat ini

1. Untuk mengetahui pengaruh antara prestasi kerja terhadap promosi jabatan pada PT. Bank Bengkulu Cabang Utama

2. Untuk mengetahui pengaruh antara senioritas terhadap promosi jabatan pada PT. Bank Bengkulu Cabang Utama

3. Untuk Mengetahui pengaruh secara simultan antara prestasi kerja dan senioritas terhadap promosi jabatan pada PT. Bank Bengkulu Cabang Utama.

\section{TINJAUAN PUSTAKA}

\subsection{Promosi Jabatan}

$$
\text { Menurut Wahyudi }
$$

menyatakan bahwa promosi adalah perubahan posisi/jabatan atau pekerjaan dari tingkat lebih rendah ke tingkat yang lebih tinggi, biasanya akan diikuti dengan meningkatnya tanggungjawab, hak, serta status sosial seseorang dan Menurut Hasibuan (2012) promosi jabatan berarti perpindahan yang memperbesar wewenang dan tanggungjawab ke jabatan yang lebih tinggi di dalam suatu organisasi yang diikuti dengan kewajiban, hak, status, dan penghasilan yang lebih besar. Dari definisi tersebut Indikator promosi jabatan menurut Wahyudi (2001:173) sebagai berikut :

1. Kejujuran, Untuk promosi jabatanjabatan tertentu mungki masalah kejujuran merupakan syarat yang penting.misalnya untuk jabatan kasir pada umumnya syarat kejujuran merupakan syarat utama yang harus diperhatikan.

2. Loyalitas, Dengan loyalitas yang tinggi dapat diharapkan antara lain tanggung jawab yang besar.
3. Tingkat pendidikan, Ada juga perusahaan yang menyaratkan minimal pendidikan untuk dapat dipromosikan pada jabatan tertentu. Alasannya bahwa dengan pendidikan yang lebih tinggi diharapkan pemikiran yang lebih baik.

4. Pengalaman kerja, Dengan pengalaman yang lebih banyak diharapkan kemampuan yang lebih tinggi, ide-ide yang lebih banyak dan sebagainya.

5. Inisiatif, Untuk kegiatan promosi pada jenis pekerjaan tertentu, barangkali karsa dan daya cipta (inisiatif) merupakan salah satu syarat yang tidak perlu ditawar lagi.

Faktor yang mempengaruhi promosi jabatan menurut Hasibuan (2005:111) adalah sebagai berikut :

1. Prestasi kerja

Karyawan itu mencapai hasil kerja yang dapat dipertanggungjawabkan kualitas maupun kuantitas, dan dapat harus bekerja secara efektif dan efesien.Hal ini menunjukkan bahwa karyawan itu dapat memanfaatkan waktu dan mempergunakan alat-alat dengan baik.

2. Disiplin

Karyawan itu harus disiplin pada dirinya, tugas-tugasnya serta mentaati peraturanperaturan yang berlaku bak tertulis maupun kebiasaan.Disiplin karyawan sangat penting karena hanya dengan disiplin ini memungkinkan perusahaan dapat mencapai hasil yang optimal. Disiplin merupakan bentuk pelatihan yang menegakkan peraturan-peraturan perusahaan dimana pegawai bekerja (Mathis, 2000) yang telah dilakukan dalam penelitian Finthariasari (2015).

3. Kecakapan

Karyawan itu cakap, kreatif dan inovatif dalam menyelesaikan tugas-tugas pada jabatan tersebut dengan baik.Karyawan harus biasa bekerja secara mandiri dalam mengerjakan pekerjaannya dengan baik 
tanpa mendapat bimbingan yang terus menerus dengan atasannya.

4. Pendidikan

Karyawan harus memiliki pengetahuan serta pendidikan formal yang sesuai dengan spesifikasi dari jabatan.

5. Kejujuran

Karyawan itu harus jujur terutama pada dirinya sendiri dengan orang lain.Perjanjian-perjanjian dalam menjalankan atau mengelola jabatan tersebut, harus sesuai dengan perbuatannya.Dia tidak menyelewengkan jabatannya untuk kepentingan pribadinya.

6. Loyalitas

Karyawan itu harus loyal dalam membela perusahaan, dari tindakan yang merugikan perusahaan. Ini menunjukkan bahwa karyawan ikut bertasipasi aktif terhadap perusahaan

7. Kepemimpinan

Pimpinan harus mampu membina dan memotivasi bawahannya untuk bekerja sama secara efektif dalam mencapai sasaran perusahaan (Finthariasari, 2015).

8. Kerja sama

Karyawan itu dapat bekerja sama secara harmonis dengan sama karyawan baik horizontal maupun vertikal dalam mencapai sasaran perusahaan.demikian akan tercipta diantara disemua karyawan.

9. Komunikatif

Karyawan harus dapat berkomunikasi secara efektif dan mampu menerima atau mempersepsikan informasi dari atasan maupun dari karyawan lainnya.

\subsection{Prestasi Kerja}

Menurut Mangkunegara (2009) prestasi kerja adalah hasil kerja secara kualitas dan kuantitas yang dicapai oleh seseorang pegawai dalam melaksanakan tugasnya sesuai dengan tanggung jawab yang diberikan kepadanya. Sementara menurut Hasibuan (2012) prestasi kerja adalah suatu hasil kerja yang dicapai seseorang dalam melaksanakan tugas-tugas yang dibebankan kepadanya yang didasarkan atas kecakapan dan kesungguhan serta waktu

Beberapa indikator prestasi kerja menurut menurut Mangkunegara (2009) sebagai berikut :

1. Kualitas, Mutu hasil kerja yang didasarkan pada standar yang ditetapkan. Biasanya diukur melalui ketepatan, ketelitian, ketrampilan, kebersihan hasil kerja.

2. Kuantitas, Banyaknya hasil kerja sesuai dengan waktu kerja yang ada, yang perlu diperhatikan bukan hasil rutin tetapi seberapa cepat pekerjaan dapat diselesaikan.

3. Pelaksanaan Tugas, Kewajiban karyawan melakukan aktivitas atau kegiatan yang berhubungan dengan pekerjaan yang ditugaskan perusahaan.

4. Tanggung Jawab, Suatu akibat lebih lanjut dari pelaksanaan peranan, baik peranan itu merupakan hak dan kewajiban ataupun kekuasaan.

Menurut Sunyoto

mengatakan bahwa dalam penilaian prestasi kerjaada macam-macam metodenya, antara lain :

1. Ratingscale. Penilaian prestasi kerja terhadap pegawai berdasarkan sifat-sifat dankarakteristik dari macam pekerjaan dan menentukan parameternya.

2. Cheklist. Penilaian yang dilakukan untuk mengurangi beban dinilai,dengan diminta laporan secara singkat mengenai perilaku yang berhubungan dengan pekerjaan pegawai.

3. Field review method. Penilaian prestasi kerja pegawai untuk mencapai penilai yang lebih standar. Dalam hal ini wakil ahli dari departemen personalia turun kelapangan membantu penilai dalam penilaian.

4. Tes dan observasi prestasi kerja. Hal ini dimaksudkan untuk menguji keterampilan-keterampilan pegawai dan 
pengetahuan yang perlu dimiliki seorang pegawai dalam menjalankan tugasnya.

5. Metode evaluasi kelompok. Penilaian prestasi kerja dengan tujuan untuk mengevaluasi pengetahuan pegawai dan kemampuan. Kemampuan pegawai dalam berbagai macam pekerjaan guna pengambilan keputusan penilaian prestasi kerja.

\subsection{Senioritas}

Senioritas menurut Wahyudi (2002) diartikan sebagai lamanya masa kerja seseorang yang diakui organisasi, baik pada jabatan yang bersangkutan maupun dalam organisasi secara keseluruhan. Selain itu, dalam senioritas tercermin pula pengertian usia serta pengalaman kerja seseorang. Manullang (2011) mengemukakan bahwa senioritas di samping dipergunakan sebagai alat pengambilan keputusan untuk tindakan promosi, sering pula dipergunakan sebagai bahan pengambilan keputusan untuk kepentingan penetapan kenaikan gaji berkala. Beberapa indikator senioritas kerja menurut Wahyudi (2002) diartikan sebagai lamanya masa kerja seseorang yang diakui organisasi, baik pada jabatan yang bersangkutan maupun dalam organisasi secara keseluruhan yaitu:

1. Senior dari segi usia

Ketika seseorang dari segi usia menjadi "senior dalam dunia kerja maka dia akan di hormati karena usianya,

2. Senior dari segi pengalaman

Seseorang dipandang sebagai senior karena dia mempunyai posisi yang tinggi dan wewenang luas.

3. Senior dari segi masa kerja

Karyawan yang memiliki masa kerja yang terlama dan lebih tinggi pengalaman dalam pekerjaan yang dilakukannya dan disebut senior oleh junior.

$$
\text { Menurut Simamora }
$$

mengemukakan bahwa senioritas sebagai berikut :
1. Senioritas dapat dianggap sebagai cara absah untuk melakukan promosi karena senioritas menghindari masalahmasalah dan sikap memihak manajemen yang memberikan kepada para karyawan yang difavoritkan kesempatan pertama untuk promosi.

2. Senioritas menghemat waktu, mudah, dan cara yang tidak menyakitkan untuk membuat keputusan promosi.

3. Biasanya ada korelasi antara senioritas dan kinerja.Sampai pada titik tertentu, para karyawan pada umumnya menjadi lebih kompeten dipekerjaannya manakala mereka menimba pengalaman.

4. Senioritas mengimbali karyawan loyal yang telah bekerja keras selamabeberapa tahun untuk menghasilkan produk dan jasa perusahaan.

\subsection{Penelitian Terdahulu}

1. Pengaruh Prestasi Kerja Terhadap Promosi Jabatan. Prestasi kerja didefinisikan sebagai seberapa baik pekerjaan dilakukan sesuai dengan standar yang ditetapkan (Mrayyan dan Ibrahim, 2008). Menurut penelitian Ramadhany (2012), prestasi kerja merupakan tingkat pelaksanaan kerja yang menunjukkan hasil kerja karyawan sesuai dengan standar yang ada dalam suatu perusahaan. Okpara (2006) menyatakan bahwa prestasi kerja karyawan menjadi salah satu dasar keputusan untuk melakukan promosi jabatan. Proses yang dilakukan perusahaan dalam mengevaluasi kinerja para pekerja sering disebut dengan penilaian prestasi kerja (Mangkuprawira, 2004). Penelitian Tajuddin (2012) menunjukkan bahwa ada hubungan positif antara prestasi kerja karyawan terhadap promosi jabatan pada PT. Semen Tonasa. Silitonga (2008) Dasar 


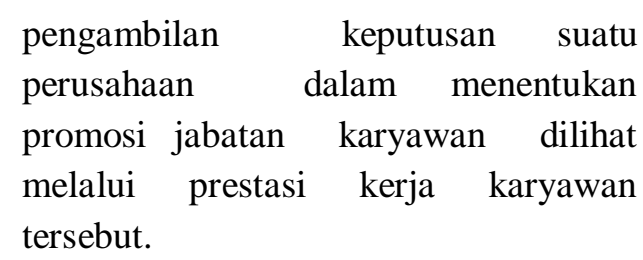

2. Pengaruh Senioritas Terhadap Promosi Jabatan. Penelitian Edmondson (2012) menyatakan bahwa senioritas merupakan faktor utama dalam promosi jabatan. Di Amerika Serikat menempatkan variable senioritas sebagai faktor penting dalam mempromosikan karyawannya. Yeh dan Jiin (2012) menyatakan bahwa, faktor senioritas cenderung lebih berpotensi dalam menentukan kesempatan promosi, dibandingkan dengan kinerja. Menurut Andhara dkk. (2015) ada pengaruh yang bersifat signifikan dari senioritas karyawan terhadap promosi jabatan. Menurut Purwaningsih dan Betty (2017) senioritas berpengaruh terhadap promosi jabatan. Jadi dari beberapa penelitian tersebut dapat disimpulkan bahwa semakin senior atau semakin lama masa kerja seseorang dalam suatu perusahaan maka semakin tinggi untuk mendapat promosi jabatan.

3. Pengaruh Prestasi Kerja Dan Senioritas Secara Bersamaan Terhadap Promosi Jabatan. Desmita, \& Kasmirudin (2015) melalukuan penelitian pada PT. Bank Panin Bandar Lampung. Penelitian Desmita menyatakan bahwa terdapat pengaruh dari variable senioritas dan prestasi kerja terhadap promosi jabatan. Senioritas dan promosi jabatan mempunyai kaitan yang kuat dalam perusahaan yaitu untuk mengurangi terjadinya kecemburuan sosial. Senioritas yang ada diperusahaan masih berpengaruh kuat dalam penentuan promosi jabatan meskipun tidak menjadi satu-satunya syarat utama dalam penentuan indikator promosi jabatan. Dengan demikian, jika karyawan dapat meningkatkan variabel prestasi kerja maka akan berdampak dalam peningkatan promosi jabatan, dengan kata lain semakin meningkatnya prestasi kerja maka akan ada peningkatan promosi jabatan. Dengan demikian, jika karyawan yang telah senior dan memiliki prstasi yang baikmaka akan mendapatkan promosi jabatan sesuai dengan kebutuhan perusahaan.

\subsection{Kerangka Penelitian}

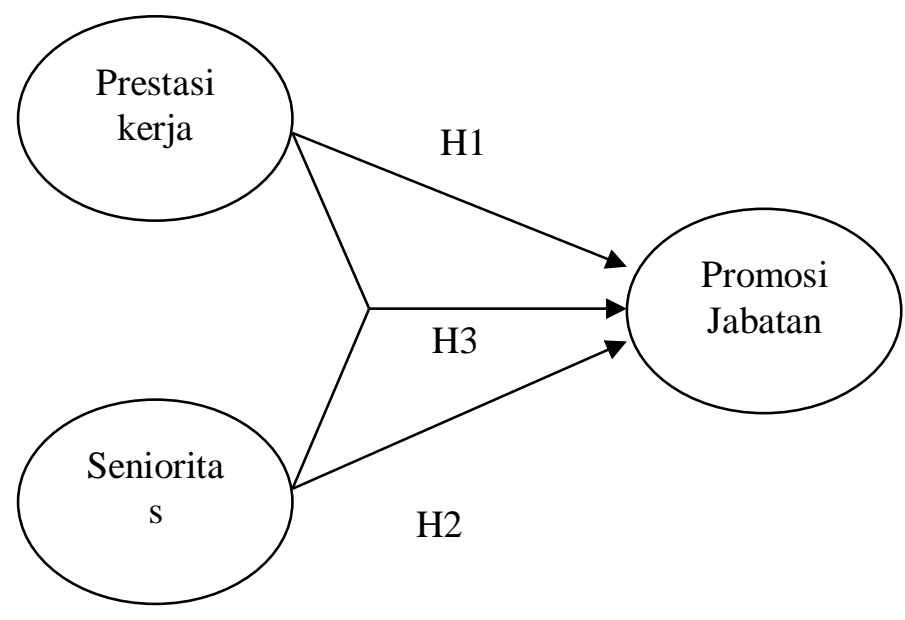

\section{Gambar 1}

\section{Kerangka Penelitian}

\subsection{Hipotesis}

$\mathrm{H} 1$ = Di duga terdapat pengaruh yang signifikan, bahwa Prestasi kerja adalah faktor yang mempengaruhi Promosi jabatan pada Karyawan PT. Bank Bengkulu Cabang Utama.

$\mathrm{H} 2$ = Di duga terdapat pengaruh yang signifikan, bahwa Senioritas adalah faktor yang mempengaruhi promosi jabatan pada Karyawan PT. Bank Bengkulu Cabang Utama.

$\mathrm{H} 3$ = Di duga terdapat pengaruh yang signifikan, bahwa Prestasi kerja dan senioritas secara bersamaan adalah faktor yang yang mempengaruhi promosi jabatan Karyawan PT. Bank Bengkulu Cabang Utama

\section{METODOLOGI PENELITIAN}

Jenis penelitian yang digunakan 
deskriptif kuantitatif. Populasi dalam penelitian ini adalah Karyawan tetap pada PT. Bank Bengkulu Cabang Utama. Jumlah sampel 60 Karyawan PT. Bank Bengkulu Cabang Utama, karena populasi dalam penelitian ini dijadikan sampel, maka metode pengambilan sampel dengan cara total sampling yaitu dengan mengambil seluruh obyek atau populasi untuk dijadikan sampel. Tahap uji instrument akan dilakukan untuk menganalisis validitas dan reliabilitas kuesioner yang akan digunakan dalam penelitian, serta uji asumsi klasik untuk menganalisis tingkat normalitas data sebelum diolah dalam tahap selanjutnya.

Data penelitian dikumpulkan dengan teknik observasi dan menyebarkan kuesioner. Setelah data terkumpul, kemudian data diolah dengan menggunakan alat analisis SPSS.

\section{HASIL DAN PEMBAHASAN}

4.1 Hasil

1. Karakteristik Responden

Tabel 1

\section{Karakteristik Responden}

Karakteristik Jumlah Presentasi

Jenis

Kelamin :

\begin{tabular}{lll}
\hline Laki-laki & 35 & 65 \\
Perempuan & 25 & 35
\end{tabular}

Pendidikan :

\begin{tabular}{lrr}
\hline SMA & 4 & 5 \\
Diploma & 14 & 11 \\
S1 & 26 & 55 \\
S2 & 16 & 29
\end{tabular}

Usia:

\begin{tabular}{lll}
\hline $17-25$ tahun & 20 & 40 \\
$26-35$ tahun & 18 & 29 \\
$36-45$ tahun & 12 & 16 \\
$>45$ tahun & 10 & 15 \\
Masa kerja : & & \\
\hline $0-11$ bulan & 0 & 0
\end{tabular}

$\begin{array}{lll}1-4 \text { tahun } & 15 & 16 \\ 5-10 \text { tahun } & 20 & 34 \\ 10 \text { tahun } & 25 & 50\end{array}$

\section{Hasil Uji Instrumen Penelitian}

Tabel 2

Uji Instrumen Penelitian

\begin{tabular}{|c|c|c|c|c|}
\hline No & Item & R-tabel & R-hitung & Keterangan \\
\hline \multicolumn{2}{|c|}{$\begin{array}{l}\text { Prestasi Kerja } \\
\text { (X1) }\end{array}$} & & & \\
\hline 1 & X1.1 & 0,423 & 0,593 & Valid \\
\hline 2 & $\mathrm{X} 1.2$ & 0,423 & 0,731 & Valid \\
\hline 3 & $\mathrm{X} 1.3$ & 0,423 & 0,820 & Valid \\
\hline 4 & X1.4 & 0,423 & 0,682 & Valid \\
\hline 5 & $\mathrm{X} 1.5$ & 0,423 & 0,647 & Valid \\
\hline 6 & X1.6 & 0,423 & 0.618 & Valid \\
\hline 7 & $\mathrm{X} 1.7$ & 0,423 & 0,522 & Valid \\
\hline 8 & $\mathrm{X} 1.8$ & 0,423 & 0,731 & Valid \\
\hline 9 & X1.9 & 0,423 & 0,695 & Valid \\
\hline 10 & $\mathrm{X} 1.10$ & 0,423 & 0,714 & Valid \\
\hline \multicolumn{2}{|c|}{$\begin{array}{l}\text { Senioritas } \\
\text { (X2) }\end{array}$} & & & \\
\hline 1 & $\mathrm{X} 2.1$ & 0,423 & 0,618 & Valid \\
\hline 2 & $\mathrm{X} 2.2$ & 0,423 & 0,522 & Valid \\
\hline 3 & $\mathrm{X} 2.3$ & 0,423 & 0,731 & Valid \\
\hline 4 & $\mathrm{X} 2.4$ & 0,423 & 0,695 & Valid \\
\hline 5 & $\mathrm{X} 2.5$ & 0,423 & 0,714 & Valid \\
\hline 6 & $\mathrm{X} 2.6$ & 0,423 & 0,593 & Valid \\
\hline 7 & $\mathrm{X} 2.7$ & 0,423 & 0,731 & Valid \\
\hline 8 & $\mathrm{X} 2.8$ & 0,423 & 0,820 & Valid \\
\hline 9 & X2.9 & 0,423 & 0,682 & Valid \\
\hline 10 & $\mathrm{X} 2.10$ & 0,423 & 0,647 & Valid \\
\hline \multicolumn{2}{|c|}{$\begin{array}{l}\text { Promosi } \\
\text { Jabatan (Y) }\end{array}$} & & & \\
\hline 1 & Y.1 & 0,423 & 0,618 & Valid \\
\hline 2 & Y.2 & 0,423 & 0,697 & Valid \\
\hline 3 & Y.3 & 0,423 & 0,697 & Valid \\
\hline 4 & Y.4 & 0,423 & 0,777 & Valid \\
\hline 5 & Y.5 & 0,423 & 0,769 & Valid \\
\hline 6 & Y.6 & 0,423 & 0,815 & Valid \\
\hline
\end{tabular}

Sumber : SPSS, 2020

Berdasarkan hasil uji validitas menggunakan score correlated item-total correlation dapat dilihat nilai dari setiap item indicator/pernyataan yang ada dalam kuesioner penelitian ini memiliki nilai lebih 
besar dari nilai rtabel yaitu hasil pengujian dapat dikatakan reliabel apabila signikansi Chronbach Alpha > 0,60. Dan lebih besar dari $\mathrm{r}$ tabel 0,423 maka dapat dikatakan valid.

Table 3

Hasil Uji Reliabilitas

\begin{tabular}{|l|c|l|}
\hline Variabel & $\begin{array}{c}\text { Cronbac } \\
\text { h Alpha }\end{array}$ & Keterangan \\
\hline $\begin{array}{l}\text { Prestasi Kerja } \\
\text { (X1) }\end{array}$ & 0,872 & $\begin{array}{l}\text { ReliabelCronbach } \\
\text { Alpha }>\text { Taraf } \\
\text { Signifikan }(0,60)\end{array}$ \\
\hline Senioritas & 0,868 & $\begin{array}{l}\text { ReliabelCronbach } \\
\text { Alpha }>\text { Taraf } \\
\text { (X2) }\end{array}$ \\
& & Signifikan $(0,60)$ \\
\hline Promosi & 0,825 & $\begin{array}{l}\text { Cronbach Alpha } \\
\text { Jabatan }\end{array}$ \\
(Y) & & $\begin{array}{l}\text { Taraf } \\
\text { Signifikan } \\
(0,60)\end{array}$ \\
\hline
\end{tabular}

Sumber : SPSS, 2020

Pada Tabel 3 di atas dapat dilihat bahwa nilai cronbach's alpha setiap variabel yang ada dalam penelitian ini di atas 0,6. Sehingga dapat disimpulkan bahwa variabel dalam penelitian ini dinyatakan reliable.

\section{Uji Asumsi Klasik}

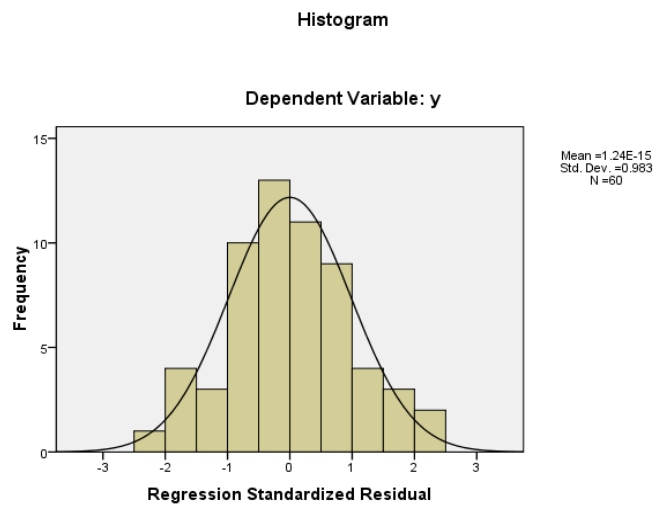

Sumber: SPSS, 2020

\section{Gambar 2}

Uji Normalitas

Dengan melihat tampilan grafik histogram, pada Gambar 2 menunjukan pola data terdistribusi secara normal, karena bentuk kurva pada histogram membentuk lengkung kurve normal maka residual dinyatakan normal dan asumsi normalitas terpenuhi.

Tabel 4

Uji Multikolinieritas

Model

Collinearity Statistics

Tolerance VIF

1 (Constant)

$\mathrm{X} 1$

.386

$\mathrm{X} 2$

.386

Sumber: SPSS, 2020

Berdasarkan Tabel 4 di atas, dapat dilihat besarnya nilai tolerance masingmasing variable dalam penelitian adalah lbih besar dari 0,10 dan nilai VIF masing-masing adalah lebih kecil dari 10, sehingga dapat disimpulkan bahwa terdapat gangguan multikolinieritas pada penelitian saat ini.

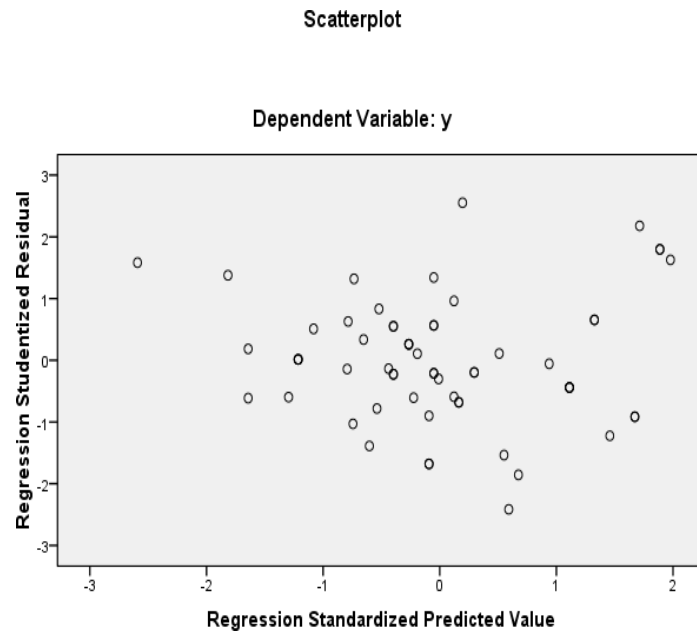

Gambar 3

\section{Hasil Uji Heteroskedastisitas}

Dari gambar tersebut diperoleh bahwa scatter plot membentuk titik- titik yang menyebar secara acak dengan tidak membentuk pola yang jelas. Hal ini menunjukkan tidak ada masalah heteroskedastisitas atau tidak mengalami heteroskedastisitas pada model regresi, sehingga model regresi layak dipakai untuk memprediksi variabel keputusan pembelian (Y). 
4. Analisis Data

\section{a. Analisis Regresi Linier Berganda}

Tabel 4

Persamaan Regresi

\section{Coefficients ${ }^{a}$}

\begin{tabular}{|c|c|c|c|c|c|}
\hline \multirow[b]{2}{*}{ Model } & \multicolumn{2}{|c|}{$\begin{array}{c}\text { Unstandardized } \\
\text { Coefficients }\end{array}$} & \multirow[t]{2}{*}{$\begin{array}{l}\text { Standardized } \\
\text { Coefficients }\end{array}$} & \multirow[b]{2}{*}{$\mathrm{T}$} & \multirow[b]{2}{*}{ Sig. } \\
\hline & B & Std. Error & & & \\
\hline 1 'onstant) & 1.924 & 1.238 & & 1.554 & .126 \\
\hline $\mathrm{x} 1$ & .490 & .053 & .817 & 9.314 & .000 \\
\hline $\mathrm{x} 2$ & .058 & .044 & .117 & 1.337 & .186 \\
\hline
\end{tabular}

a. Dependent Variable: y

Sumber : Output SPSS, 2020

Berdasarkan Tabel 4 di dapat persamaan regresi sebagai berikut: $\mathrm{Y}=\mathbf{1 . 9 2 4}+\mathbf{0 , 4 9 0 X 1}+\mathbf{0 , 5 8} \mathrm{X2}$

Keterangan:

$$
\begin{array}{ll}
\mathrm{Y} & =\text { Promosi Jabatan } \\
\mathrm{X}_{1} & =\text { Prestasi kerja } \\
\mathrm{X}_{2} & =\text { Senioritas }
\end{array}
$$

Untuk menganalisis koefisien regresi masing-masing variabel dalam penelitian ini dapat dijelaskan sebagai berikut :

1. Nilai konstanta 1.924 mempunyai arti bahwa apabila variabel Prestasi kerja (X1), Senioritas (X2), dianggap tetap maka variabel Promosi Jabatan (Y) akan tetap sebesar 1.924. Hal ini berlaku saat dilaksanakannya penelitian.

2. Pengaruh Prestasi Kerja (X1) terhadap Promosi Jabatan (Y). Nilai koefesien regresi variabel X1 (Prestasi kerja) adalah sebesar 0,490 dengan asumsi apabila X1 (Prestasi Kerja) mengalami kenaikan sebesar satu- satuan maka $\mathrm{Y}$ (Promosi Jabatan) juga akan mengalami kenaikan sebesar 0,490 kali

3. Pengaruh Senioritas terhadap Promosi Jabatan. Nilai koefesien regresi variabel $\mathrm{X} 2$ (Senioritas) adalah sebesar 0,58 dengan asumsi apabila X2 (Senioritas) mengalami kenaikan sebesar satu-satuan maka Y (Promosi Jabatan) juga akan mengalami kenaikan sebesar 0,58 kali.

\section{b. Hasil Uji Koefisien Determinasi $\left(\mathbf{R}^{\mathbf{2}}\right)$}

Tabel 5

Uji Koefisien Determinasi $\left(\mathbf{R}^{\mathbf{2}}\right)$

\begin{tabular}{|r|r|r|r|r|r|}
\hline \multicolumn{1}{|c|}{ Model Summary } \\
\hline Model & \multicolumn{1}{|c|}{$\mathrm{R}$} & R Square & $\begin{array}{l}\text { Adjusted R } \\
\text { Square }\end{array}$ & $\begin{array}{l}\text { Std. Error } \\
\text { of the } \\
\text { Estimate }\end{array}$ & $\begin{array}{l}\text { Durbin- } \\
\text { Watson }\end{array}$ \\
\hline 1 & $.911^{\mathrm{a}}$ & .831 & .825 & 1.29970 & 2.616 \\
\hline
\end{tabular}

a. Predictors: (Constant), x2, x1

b. Dependent Variable: y

Sumber : Output SPSS, 2020

Untuk nilai koefesien determinasi menggunakan model $R$ square. Dari hasil perhitungan dengan menggunakan SPSS dapat diketahui nilai koefesien determinasi dari $R$ square yaitu sebesar 0,831 . Hal ini berarti bahwa X1 (Prestasi kerja), X2 (Senioritas), memiliki kontribusi terhadap Promosi Jabatan (Y) sebesar 8,31\% sedangkan sisanya $1,69 \%$ dipengaruhi oleh variabel-variabel lainnya yang tidak diteliti dalam penelitian ini.

\section{Uji Hipotesis}

a. Uji T (Parsial)

Hasil uji yang didasarkan pada pengujian spss untuk melihat apakah setiap variabel-variabel masing - masing yang diteliti dapat berpengaruh secara signifikan dengan ketentuan standart signifikan apabila hasil yang didapat lebih meningkat maka Hipotesis diterima dan sebaliknya jika hasil yang didapat tidak sesuai dengan diatas signifikan 0,05 dan standart ketentuan $\mathrm{t}$ hitung dan $\mathrm{t}$ tabel maka hipotesis ditolak. 
Tabel 6

Hasil Uji T (Parsial)

Coefficients $^{\mathbf{a}}$

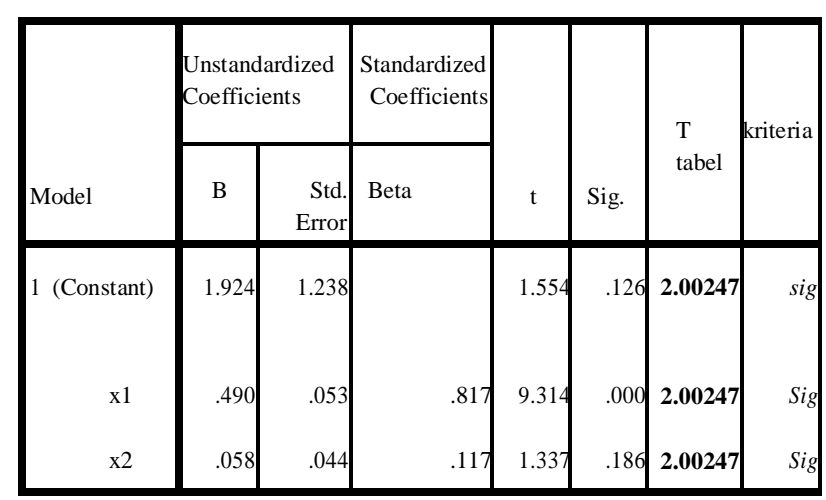

a. Dependent Variable: y

Sumber : Output SPSS, 2020

Berdasarkan hasil uji $\mathrm{t}$ (secara parsial) yang ditunjukan pada Tabel 4.6 di atas dapat dianalisis sebagai berikut:

1. Pengaruh Variabel X1 (Prestasi kerja ) terhadap Promosi Jabatan

Dari output di atas dapat dilihat bahwa Thitung dengan Ttabel > ( $9.314>$ 2.00247) dan ( $\operatorname{sig} \mathrm{a}=0,010<0,050)$, hal tersebut menyatakan hal menyatakan bahwa $\mathrm{H}_{1}$ diterima yaitu adanya pengaruh variabel prestasi kerja $\left(\mathrm{X}_{1}\right)$ secara positif dan signifikan terhadap Promosi Jabatan (Y) pada Pada PT. Bank Bengkulu Cabang Utama.

2. Pengaruh Variabel $\mathrm{X}_{2}$ (Senioritas) terhadap Promosi Jabatan

Hasil pengujian untuk variabel $\mathrm{X}_{2}$ (Senioritas) menunjukkan nilai Thitung dengan Ttabel $>(1.337<2.00247)$ dan (sig a $=0,010<0,050)$ hal tersebut menyatakan bahwa hal tersebut menyatakan bahwa $\mathrm{H}_{2}$ ditolak yaitu tidak ada pengaruh variabel Senioritas $\left(\mathrm{X}_{2}\right)$ secara negatif dan dengan signifikansi diatas 0,05 terhadap Promosi Jabatan (Y) pada Pada PT. Bank Bengkulu Cabang Utama.

\section{b. Uji F (Simultan)}

Table 7

Hasil Uji F (Simultan) ANOVA ${ }^{b}$

\begin{tabular}{|l|c|c|r|r|r|}
\hline Model & $\begin{array}{l}\text { Sum of } \\
\text { Squares }\end{array}$ & df & Mean Square & F & Sig. \\
\hline 1 Regression & 472.297 & 2 & 236.149 & 139.797 & $.000^{\mathrm{a}}$ \\
Residual & 96.286 & 57 & 1.689 & & \\
Total & 568.583 & 59 & & & \\
\hline
\end{tabular}

a. Predictors: (Constant), x2, x1

b. Dependent Variable: y

Sumber : Output SPSS, 2020

Berdasarkan tabel uji hipotesis dengan uji $\mathrm{F}$ diatas diperoleh Fhitung sebesar dengan Nilai Ftabel $=(\mathrm{k} ; \mathrm{n}-\mathrm{k})=(2$; $60-2)=2 ; 57=3.16$ yaitu $(139.797>3.16)$ maka dengan demikian dapat disimpulkan bahwa $\mathrm{H}_{3}$ diterima artinya secara simultan variabel Prestasi kerja $\left(\mathrm{X}_{1}\right)$, Senioritas (X2) berpengaruh secara simultan atau bersama-sama terhadap Promosi Jabatan (Y) di Pada PT. Bank Bengkulu Cabang Utama .

\subsection{Pembahasan}

\section{Pengaruh Variabel Prestasi Kerja Terhadap Promosi Jabatan}

Dari hasil analisis yang telah dipaparkan diatas, dapat peneliti simpulkan bahwa variable Prestasi kerja memiliki pengaruh yang positif signifikan terhadap Promosi jabatan pada karyawan PT Bank Bengkulu Cabang Utama. Artinya bahwan hipotesis pertama yang diajukan dalam penelitian ini diterima. Sejalan dengan teori dan hasil penelitian yang telah dipaparkan sebelumnya dalam Bab 2 di atas, yang menyatakan bahwa variable Prestasi kerja memiliki pengaruh positif terhadap Promosi jabatan. Banyak studi membahas mengenai Prestasi kerja dan pengaruhnya 
terhadap variabel Promosi Jabatan. Menurut Mangkunegara prestasi kerja adalah hasil kerja secara kualitas dan kuantitas yang dicapai oleh seseorang pegawai dalam melaksanakan tugasnya sesuai dengan tanggung jawab yang diberikan kepadanya.karyawan dapat dikatakan memiliki prestasi kerja yang baik apabila dapat memberikan hasil terbaik dengan pekerjaan artinya karyawan yang memiliki prestasi kerja yang melampaui standar ketentuan yang dibuat oleh perusahaan dengan memperhatikan kebijaksanaan-kebijaksanaan yang melalui penilaian prestasi kerja untuk mendorong karyawan dalam meningkatkan prestasi kerja sebagai bahan pengambilan keputusan dalam pemberian upah maupun jabatan yang lebih tinggi sebagai partisipasi pihak perusahaan untuk memberikan penghargaan yang sesuai berupa promosi jabatan pada karyawan yang mampu dan layak untuk dapat dipromosikan.

Menurut Penelitian Tajuddin (2012) menunjukkan bahwa ada hubungan positif antara prestasi kerja karyawan terhadap promosi jabatan pada PT. Semen Tonasa. Silitonga (2008) Dasar pengambilan keputusan suatu perusahaan dalam menentukan promosi jabatan karyawan dilihat melalui prestasi kerja karyawan tersebut.Penelitian yang dilakukan Padjalangi (2009) prestasi kerja dengan promosi jabatan pada PT. BNI, Tbk.Benson et.al. (2002) menyatakan bahwa umumnya proses promosi jabatan dilakukan dengan mempertimbangkan kompetensi individu, pengalaman individu, dan kebutuhan organisasi.

\section{Pengaruh Variabel Senioritas Terhadap Promosi jabatan}

Hasil analisis yang telah dipaparkan diatas, dapat disimpulkan bahwa variable Senioritas memiliki pengaruh yang positif signifikan terhadap Promosi jabatan pada PT. Bank Bengkulu Cabang Utama. Artinya bahwan hipotesis kedua yang diajukan dalam penelitian ini diterima. Sejalan dengan teori dan hasil penelitian yang telah dipaparkan sebelumnya dalam Bab 2 di atas, yang menyatakan bahwa variable Senioritas memiliki pengaruh positif terhadap Promosi Jabatan.

Menurut Yeh dan Jiin (2012) menyatakan bahwa, faktor senioritas cenderung lebih berpotensi dalam menentukan kesempatan promosi, dibandingkan dengan kinerja. Menurut Andhara dkk. (2015) ada pengaruh yang bersifat signifikan dari senioritas karyawan terhadap promosi jabatan. Menurut Purwaningsih dan Betty (2017) senioritas berpengaruh terhadap promosi jabatan. Jadi semakin senior atau semakin lama masa kerja seseorang dalam suatu perusahaan maka semakin tinggi untuk mendapat promosi jabatan.

Berdasarkan teori yang disampaikan oleh Senioritas menurut Wahyudi (2002) diartikan sebagai lamanya masa kerja seseorang yang diakui organisasi, baik pada jabatan yang bersangkutan maupun dalam organisasi secara keseluruhan. Jadi semakin senior atau semakin lama masa kerja seseorang dalam suatu perusahaan maka semakin tinggi untuk mendapat promosi jabatan.

\section{Pengaruh Variabel Prestasi Kerja dan} Senioritas Terhadap Promosi Jabatan

Jika dilihat dari hasil analisis perhitungan table uji $\mathrm{T}$ yang telah dipaparkan di atas, serta pembahasan hasil penelitian mengenai pengaruh antara variable independen (X1, X2, dan X3) terhadap variable dependen (Y) secara parsial. Bahwa masing-masing variable independen (X1, X2, dan X3) memiliki pengaruh positif yang signifikan terhadap variable dependen $(\mathrm{Y})$. Kemudian untuk hasil analisis uji $\mathrm{F}$ menyatakan bahwa secara simultan pun menunjukan bahwa variable independen (X1, X2, dan X3) memiliki pengaruh positif yang signifikan terhadap variable dependen (Y). 
Hubungan positif signifikan secara simultan dan telah diuji antara 2 variabel independen dan dependen ini terjadi karena adanya hubungan positif yang disumbangkan dari masing-masing variabel independen terhadap variabel dependen.

\section{KESIMPULAN}

1. Prestasi Kerja $\left(\mathrm{X}_{1}\right)$ berpengaruh positif terhadap Promosi jabatan (Y) pada Pada PT, Bank Bengkulu Cabang Utama, yang dapat dibuktikan dari hasil uji $\mathrm{T}$ dibawah 0,010 dengan signifikansi dibawah 0,050. bahwa $\mathrm{H} 1$ diterima.

2. Senioritas $\left(\mathrm{X}_{2}\right)$ tidak berpengaruh terhadap promosi jabatan pada PT.Bank Bengkulu Cabang Utama, yang dapat dibuktikan dengan hasil Uji $\mathrm{T}$ dibawah 0.010 dan signifikansi diatas 0,050 . bahwa $\mathrm{H}_{2}$ ditolak.

3. Prestasi kerja $\left(\mathrm{X}_{1}\right)$, Senioritas $\left(\mathrm{X}_{2}\right)$, secara bersama- sama atau simultan berpengaruh terhadap Promosi jabatan (Y) pada Pada PT. Bank Bengkulu Cabang Utama, yang dibuktikan dengan hasil uji $\mathrm{F}$ dengan signifikasi dibawah 0,050 . bahwa $\mathrm{H} 3$ diterima.

\section{SARAN}

Dalam penelitian ini dikatakan bahwa Pomosi jabatan adalah baik, namun hal ini terjadi karena variable yang diteliti dalam penelitian ini adalah variable Prestasi kerja dan Senioritas dimana dua variable ini ditanggapi baik oleh para responden yang ada.

1. Disarankan kepada pimpinan PT. bank Bengkulu Cabang Utama sebaiknya lebih memperhatikan para pegawai yang memiliki masa kerja yang lama dan memiliki prestasi kerja yang lebih baik dan bagus membuktikan bahwa pegawai tersebut loyal dan berprestasi kepada perusahaan sehingga pantas untuk diberikan peluang promosi jabatan yang lebih tinggi. pegawai tersebut loyal dan berprestasi kepada perusahaan sehingga pantas untuk diberikan peluang promosi jabatan yang lebih tinggi.

2 Yang diharapkan dari PT. Bank Bengkulu Cabang Utama untuk lebih memperhatikan kinerja karyawan tidak dilihat dalam masa kerjanya tetapi dilihat dari skiil dan pengetahuannya sebagai upaya untuk memperbaiki, meningkatkan kinerja dan dapat meningkatkan promosi jabatan pada PT. Bank Bengkulu Cabang Utama.

3. Penulis juga menyarankan Senioritas juga harus diterapkan dengan adil tanpa memihak kepada siapapun, serta senioritas yang dipandang melalui pengalaman bekerja, penilaian prestasi kerja, dan persyaratan yang sudah ditentukan sehingga tidak ada kecemburuan sosial antar karyawan.

4. Bagi peneliti, diharapkan di masa yang akan datang penelitian ini dapat digunakan sebagai salah satu acuan untuk penelitian selanjutnya dengan menggunakan variabel independen yang berbeda yang berpengaruh terhadap promosi jabatan dan dilakukan berdasarkan faktor lain.

\section{DAFTAR PUSTAKA}

[1] Ardana, dkk. 2012. Manajemen Sumber Daya Manusia. Yogyakrta : Graha Ilmu.

[2] Arikunto, Suharsimi, 2010. Prosedur Penelitian Suatu Pendekatan Praktek, Jakarta. Penerbit Rineka Cipta, Jakarta

[3] Aulia Purwaningsi, Betty Magdelena. Pengaruh Senioritas Dan Prestasi Kerja terhadap Promosi Jabatan Pada Karyawan, Jurnal : Institut Informatika dan Bisnis Darmajaya 
[4] Alia Dwi Siska, Suryalena. Pengaruh Prestasi Kerja dan Loyalitas terhadap Promosi Jabatan Pada Karyawan, Jurnal : Kampus Bina Widya

[5] Desmita, Lusia., Kasmiruddin. 2015. Pengaruh Senioritas dan Loyalitas Terhadap Promosi Jabatan, Jurnal : Kampus Bina Widya

[6] Dessler, Garry. 2008. Manajemen Sumber Daya Manusia, Jakarta: PT. Prenhalindo.

[7] Fathoni, Abdurrahmat. 2006. Manajemen Sumber Daya Manusia. Jakarta: PT Rineka Cipta.

[8] Finthariasari, Meilaty., Dewi, Rahmayanti. (2015). Peranan Pemimpin terhadap Disiplin Pegawai Kementerian Agama Provinsi Bengkulu Kelompok Jabatan Fungsional, Jurnal : Jurusan Manajemen FEB Univ. Muhammadiyah Bengkulu, 2(7).

[9] Finthariasari, Meilaty., Ekowati, Sri., Ranidiah, Furqonti., Yuniarti, Rina., Muchlis. (2020). Pengaruh Work Family Conflict Terhadap Turnover Intention Melalui Komitmen Organisasi. Ekuitas (Jurnal Ekonomi dan Keuangan), 4(3): 421-438.

[10] Handoko Hani T. 2008. Manajemen Personalia dan Manajemen Sumber Daya Manusia (Edisi 2). Yogyakarta. BPFE.

[11] Hariyandi. Rahmat dan Susi Hendriani. 2014. Manajemen Sumber Daya Manusia (Human Resource) Suatu Pendekatan Mikro, Djanbatan, Jakarta.

[12] Hasibuan, Malayu. 2010. Manajemen
Sumber Daya Manusia. Cetakan

Kesembilan. Jakarta : Bumi Aksara.

[13] Hasibuan, Malayu S.P. 2012. Manajemen Sumber Daya Manusia. Bumi Aksara. Jakarta

[14] Handoko, Hani T. 1997. Manajemen Personalia dan Manajemen Sumber Daya Manusia.Yogyakarta: BPFE.

[15] Mangkuprawira. 2004. Perencanaan Manajemen Sumber Daya Manusia. CV : Budi Utama

[16] Sepriansya, Ige., Ratnawili, Ratnawili, Finthariasari, Meilaty. (2020). Pengaruh Gaya Kepemimpinan, Semangat Kerja, Dan Kompensasi Terhadap Kinerja Karyawan PT. Syandi Putra Makmur Cabang Kota Bengkulu. Jurnal Entrepreneur dan Manajemen Sains (JEMS), 1(2).

[17] Martoyo, Susilo. 2012. Manajemen Sumber Daya Manusia. Edisi Kedelapan. Yogyakarta : BPFE.

[18] Manullang. 1976. Management Personalia. Medan: Ghalia Indonesia. Mangkunegara, A.A. Anwar Prabu. 2000 dan 2001. Manajemen Sumber Daya.

[19] Mangkuprawira. 2004. Perencanaan Manajemen Sumber Daya Manusia. CV : Budi Utama.

[20] Mulyono Yudi. 2012. Pengaruh Prestasi Kerja dan Disiplin Kerja Terhadap Promosi Jabatan pada PT. Asuransi Jiwa Squislife Bandar Lampung.

[21] Nitisemito, Alex. S. 2002. Manajemen Personalia. Edisi Revisi, Yogyakarta: Penerbit Ghalia 
Indonesia.

[22] Okpara. 2006. UKM Ekonomi Kreatif. Uwais inspirasi Indonesia.

[23] Sari, Putri Mayang., Ekowati, Sri., Finthariasari, Meilaty. Pengaruh Sikap dan Disiplin Kerja Terhadap Prestasi Kerja Karyawan PT. Prioritas Kota Bengkulu. Jurnal Entrepreneur dan Manajemen Sains (JEMS), 1(2).

[24] Simamora, Henry. 2004. Manajemen Sumber Daya Manusia. Edisi Ketiga. Yogyakarta: STIE YKPN. 